\title{
River bank erosion risk potential with regards to soil erodibility
}

\author{
Z. A. Roslan ${ }^{1}$, Y. Naimah ${ }^{1}$ \& Z. A. Roseli ${ }^{2}$ \\ ${ }^{1}$ Infrastructure University, Kuala Lumpur, Malaysia \\ ${ }^{2}$ Humid Tropics Centre, Kuala Lumpur, Malaysia
}

\begin{abstract}
River bank failures are a common scenario in Malaysia especially during heavy rainy seasons. One of the significant factors causing river bank erosion is the textural composition along the river banks which can be presented by the degree or level of soil erodibility. Sieve analysis and hydrometer tests were conducted for all soil samples collected along the river bank and the "ROM" scale (after the name of the researchers ROslan and Mazidah) is used to determine the degree of soil erodibility namely low, moderate, high, very high and critical along the river bank based on the percentage composition of sand, silt and clay. By determining the soil erodibility level, the risk of river bank failure at any location along the river bank can be made known. Thus, this valuable information would certainly enable the concerned government and private authorities to plan, design and construct the most suitable preventive measures in arresting river bank erosion. Keywords: river bank, textural composition, soil erodibility, “ROM” scale.
\end{abstract}

\section{Introduction}

Riverbank erosion is one of the major and unpredictable problems worldwide [1] which occurs both naturally and through human impact. The erosion involves the wearing away of soil found along the river bed and banks that will lead to the accumulation of sediment which in turn will increase the river pollution problem. The amount of soil erosion loss depends on the combination of the strength of the rain to cause erosion and the ability of the soil to withstand the rain. The soil resistance against erosion is termed as soil erodibility and the value depends on several factors such as soil structure, infiltration level and organic matter content. 
In Malaysia, the mean suspended sediment concentration in the rivers due to soil erosion rose by 34\% in 1998 [2] and nowadays, river contributes to 95 percent of sediments entering the ocean [3]. The soil texture of Langat River which is of concerned in this research has been found totally differed from previous study that recorded mostly loam clay as the main soil texture [4]. During rainfall, sediments and eroded soil are flushed out to the downstream and sedimentation will take place, resulting to the rivers become milky and the downstream become shallower. This situation leads to water scarceness, flash flood and other environmental problems. The trend of sediment production may increase in future due to rapid development activities.

Generally, erosion features can be classified into three types namely sheet, rill and gully erosion. Sheet Erosion is the most common and most likely the least damaging form of erosion by water. Normally the thin layer of soil is detached

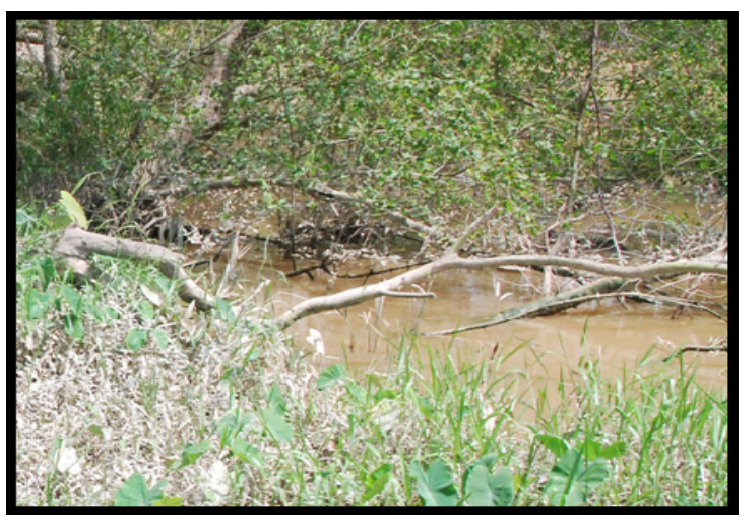

Figure 1: $\quad$ Typical sheet erosion along Langat River at Kuala Langat district.

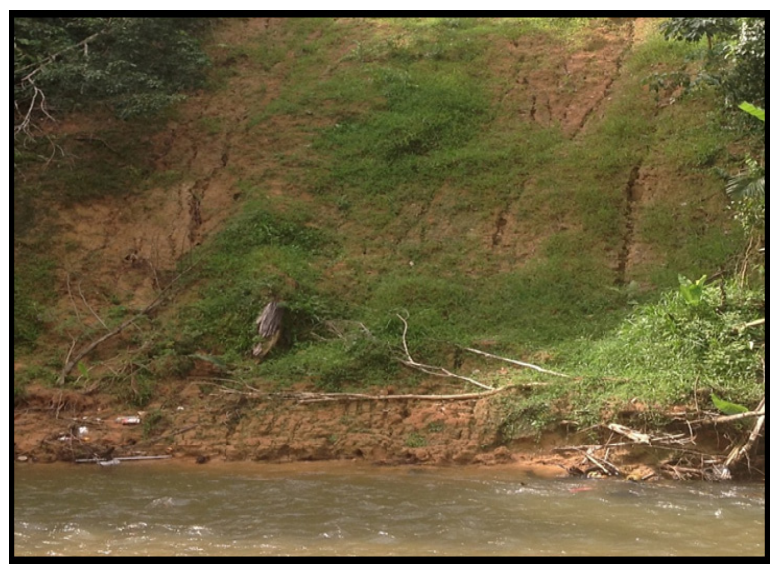

Figure 2: $\quad$ Typical rill erosion along Langat River at Hulu Langat district. 


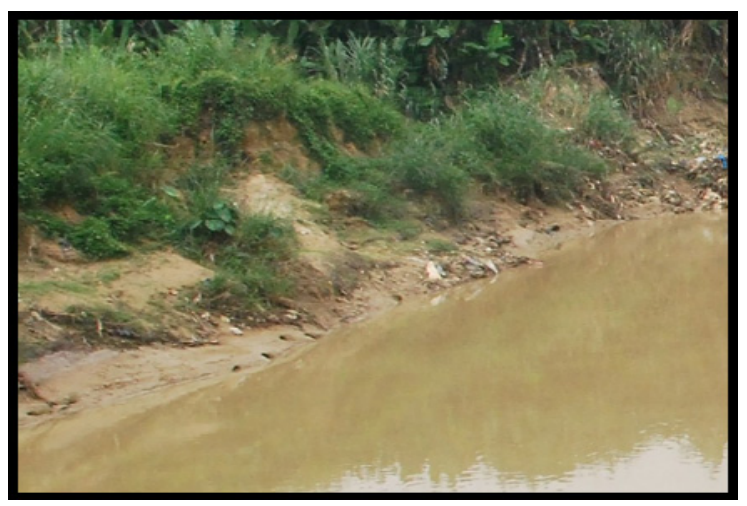

Figure 3: $\quad$ Typical gully erosion along Langat River at Sepang district.

by the falling rain drops and then removed by surface runoff. Rill erosion can be classified as moderate, the range is between sheet and gully erosion. The occurrence of this erosion depends on the accumulation of rainwater after the rainfall event. Normally, rill erosion erodes downwards and may extend into the subsoil, leading to gully erosion in a short time. Gully erosion can be defined as the most erosive process compared to sheet and rill erosion that mostly causes a great amount of soil loss and then contributes to shape the earth surface [5]. Normally gully erosion is a result of continuous flowing of water through rill erosion. Figures 1 to 3 shows the sheet, rill and gully erosion respectively.

\section{Soil erodibility}

Erodibility defines the resistance of the soil to both detachment and transport, although many other factors such as topography and soil management may affect soil erodibility. Any property that prevents or makes soil detachment or soil transportation difficult can reduce soil erodibility. Texture and structure certainly affect the size of grains exposed to erosive elements. As runoff must occur for rapid erosion to take place, soil properties that affect infiltration rate and permeability also affect the rate of erosion. Therefore, soil texture and structure must be the most important determinants of soil erodibility [6]. The role of soil texture has been indicated earlier where large particles are resistant to transport because greater force is required to move them and that fine particles are resistant to detachment because of their cohesiveness. The least resistant particles are silts and sands, thus soils with high silt and sand content are highly erodible.

Many attempts have been made to devise a simple index of erodibility based either on the properties of the soil as determined in the laboratory or the field, or on the response of the soil to rainfall. Theoretically the use of clay content as an indicator of erodibility was found to be more satisfying, when the clay particles combine with organic matter to form soil aggregates or clods. It is the stability of these which determines the resistance of the soil [7]. The clay ratio as shown in 
Equation (1) to determine the Bouyoucos erodibility index [8], has led to the development of the $\mathrm{EI}_{\mathrm{ROM}}$ equation.

$$
\text { Bouyoucos erodibility index }=\frac{\% \text { Sand }+\% \text { Silt }}{\% \text { Clay }}
$$

An advance and new improved soil erodibility index was then developed by the name of $\mathrm{EI}_{\mathrm{ROM}}$ or 'ROM' Scale [6]. This new equation is still using the original principal of Bouyoucos which is analyzing the soil textural composition of sand, silt and clay. The new equation clearly has shown the significant value and threshold for soil erodibility demarcation and at the same time indicated the expected erosion feature. With the new $\mathrm{EI}_{\mathrm{ROM}}$ equation as in Equation (2), the more realistic and significant value of soil erodibility index can be used simultaneously with its risk category as shown in Table 1 to indicate the degree of soil erodibility.

$$
\mathrm{EI}_{\mathrm{ROM}}=\frac{\% \text { Sand }+\% \text { Silt }}{2(\% \text { Clay })}
$$

Table 1: $\quad$ 'ROM’ Scale with regards to soil erodibility category.

\begin{tabular}{|c||c|}
\hline 'ROM' Scale & Soil Erodibility Category \\
\hline$<1.5$ & Low \\
\hline $1.5 \sim 4.0$ & Moderate \\
\hline $4.0 \sim 8.0$ & High \\
\hline $8.0 \sim 12.0$ & Very High \\
$>12.0$ & Critical \\
\hline
\end{tabular}

\subsection{The 'ROM' scale}

The establishment of the 'ROM' scale was based merely on soil grading characteristics and it uses $\mathbf{E I}_{\mathbf{R O M}}$ equation in order to obtain the soil erodibility index besides its indicator of the erosion features configuration. In other words, the 'ROM' scale is used to measure the degree of soil erodibility based on $\mathbf{E I}_{\mathbf{R O M}}$ equation. This is the first ever scale that has been developed to grade the degree of erosion with regards to soil erodibility index and erosion features. In the initial stage of 'ROM' scale development, a number of areas and locations in Peninsular Malaysia where erosion induced landslide had occurred were identified. Physical reconnaissance and observation of soil erosion features with basic information about soil classification at the identified areas were recorded. The impact of soil erosion process on the affected areas recognized from the erosion features that are commonly known as sheet, rill and gully were critically observed. The identification of the soil textural composition namely sand, silt and clay is crucial in establishing erosion induced landslide risk. The $\mathbf{E I}_{\mathbf{R O M}}$ equation as mentioned earlier was created to obtain an acceptable sound erodibility values compared to other scale of measurements. 


\section{Methodology}

A total of 120 soil samples were collected for every $5 \mathrm{~km}$ interval using hand auger for the depth of $1 \mathrm{~m}$ along the Langat River. Figure 4 shows the map of Langat River basin where it passes through three districts namely Hulu Langat, Sepang and Kuala Langat in the state of Selangor, Malaysia. The laboratory testing namely sieve and hydrometer analysis was conducted to analyse the percentage of soil texture composition. Sieve analysis was carried out to determine the percentage of different grain sizes contained within a soil. In this experiment, the equipment needed are test sieve that have nominal maximum sieve size $6.300 \mathrm{~mm}, 5.000 \mathrm{~mm}, 3.350 \mathrm{~mm}, 2.000 \mathrm{~mm}, 1.180 \mathrm{~mm}, 0.600 \mathrm{~mm}$, $0.425 \mathrm{~mm}, 0.300 \mathrm{~mm}, 0.212 \mathrm{~mm}, 0.150 \mathrm{~mm}$ and $0.063 \mathrm{~mm}$. Distribution of the finer particles less than $0.063 \mathrm{~mm}$ was determined by hydrometer method. Finally "ROM" software was used to determine the degree of erosion risk and the scale as shown in Table 1.

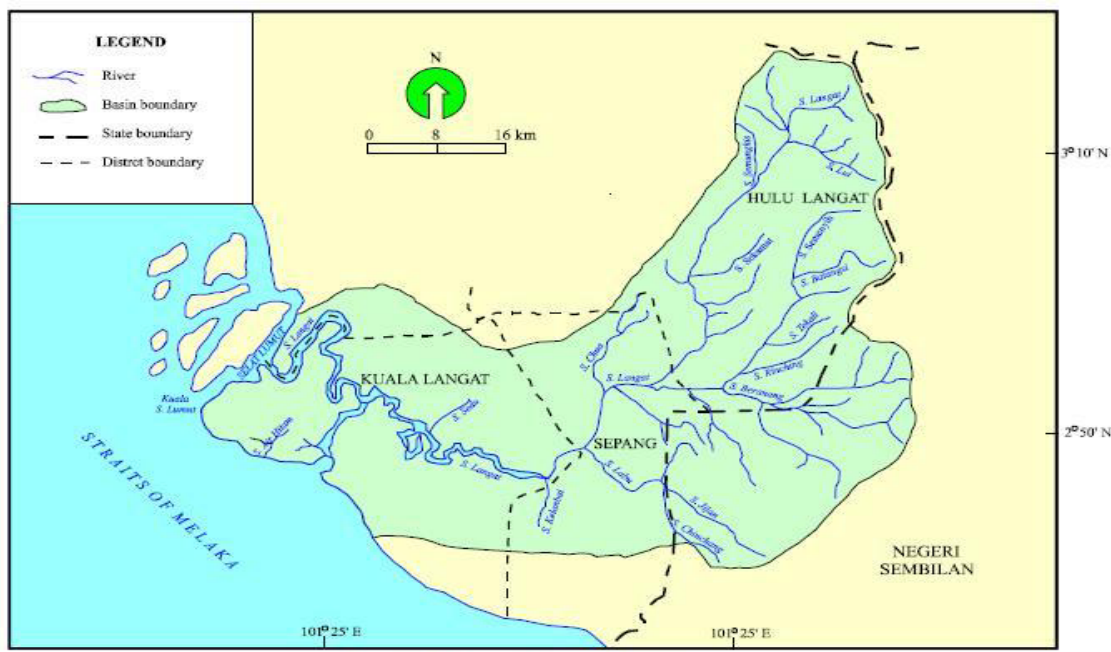

Figure 4: $\quad$ Map of Langat River basin (Department of Irrigation and Drainage, 2007).

\section{Results and discussion}

The results of the dry sieving and hydrometer test for some of the soil samples collected were tabulated in Table 2.

The degree of erosion risk in terms of percentage for the three districts along Langat River namely Hulu Langat, Sepang and Kuala Langat district were shown in Figure 5,6 and 7 respectively. 
Table 2: $\quad$ Soil textural composition along Langat River.

\begin{tabular}{|c|c|c|c|c|}
\hline \multirow{3}{*}{ District } & \multirow{2}{*}{ Sample } & \multicolumn{3}{|c|}{ Soil Textural Composition } \\
\cline { 2 - 5 } & & Sand(\%) & Silt(\%) & Clay(\%) \\
\hline \multirow{3}{*}{ Hulu Langat } & 1 & 71.81 & 26.47 & 0.18 \\
\cline { 2 - 5 } & 2 & 51.06 & 38.78 & 5.36 \\
\cline { 2 - 5 } & 3 & 39.12 & 54.84 & 6.04 \\
\cline { 2 - 5 } & 4 & 13.36 & 75.06 & 8.47 \\
\hline \multirow{3}{*}{ Sepang } & 1 & 54.74 & 42.84 & 0.07 \\
\cline { 2 - 5 } & 2 & 36.68 & 61.16 & 0.92 \\
\cline { 2 - 5 } & 3 & 18.80 & 70.90 & 10.20 \\
\hline \multirow{3}{*}{\begin{tabular}{c} 
Kuala \\
\cline { 2 - 5 }
\end{tabular}} & 4 & 2.80 & 55.35 & 41.79 \\
\cline { 2 - 5 } & 2 & 5.52 & 62.61 & 22.71 \\
\cline { 2 - 5 } & 3 & 12.22 & 76.85 & 3.89 \\
\cline { 2 - 5 } & 4 & 1.02 & 66.52 & 33.38 \\
\hline
\end{tabular}

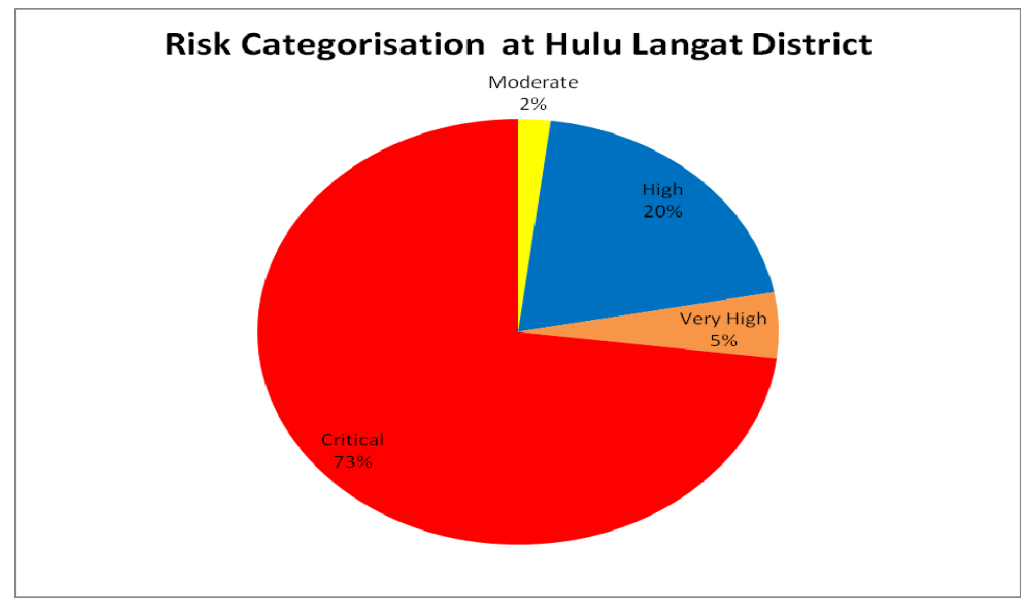

Figure 5: $\quad$ Percentage of erosion risk level at Hulu Langat district.

From Figure 5 to 7, it can be seen that Hulu Langat district was identified as the highest potential of riverbank erosion risk due to the highest percentage of $73 \%$ recorded as critical degree of erosion risk with regards to "ROM" scale classification. It means that the soil erodibility at Hulu Langat district were highly erodable. Meanwhile, the critical degree of erosion risk for Kuala Langat was the lowest since the percentage was only 5\%. Figures 8, 9 and 10 show a typical soil composition and erosion features at Hulu Langat, Sepang and Kuala Langat district respectively. 


\section{Risk Categorisation at Sepang District}

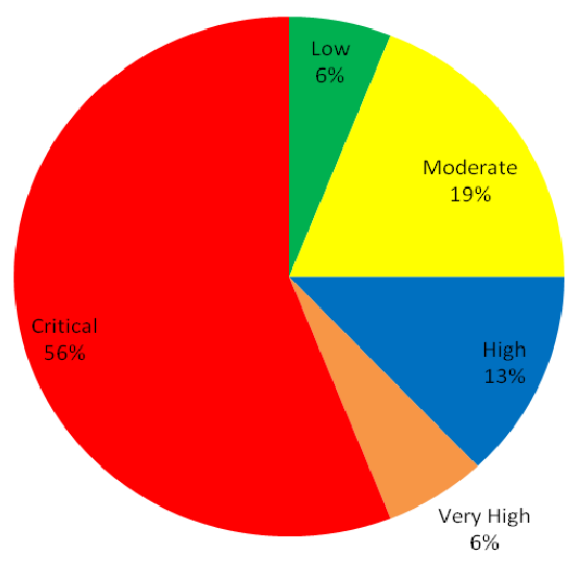

Figure 6: $\quad$ Percentage of erosion risk level at Sepang district.

\section{Risk Categorisation at Kuala Langat District}

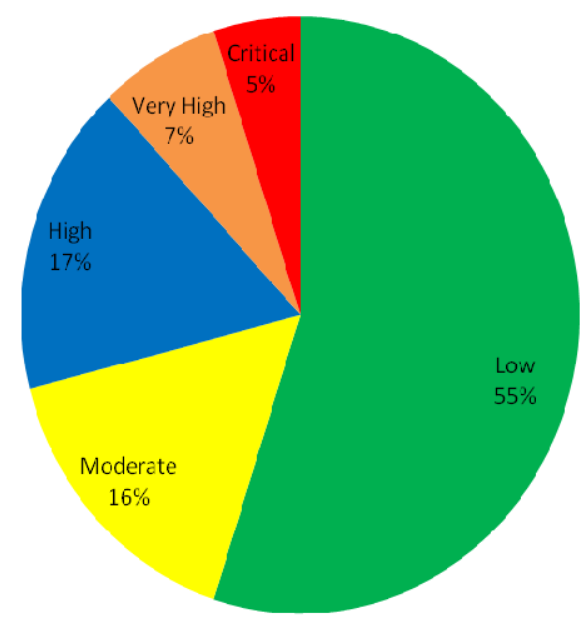

Figure 7: $\quad$ Percentage of erosion risk level at Kuala Langat district. 


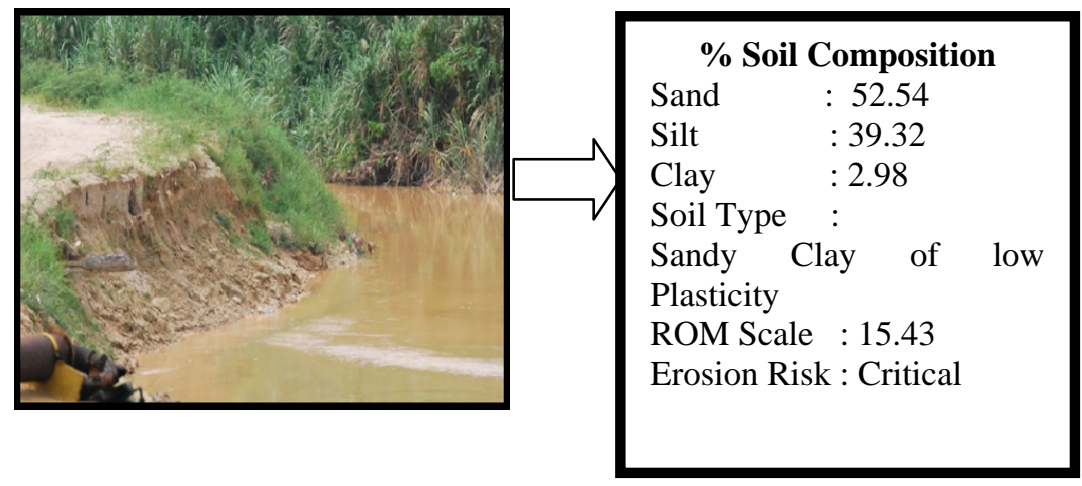

Figure 8: $\quad$ Langat River at Taman Mahkota, Hulu Langat district.

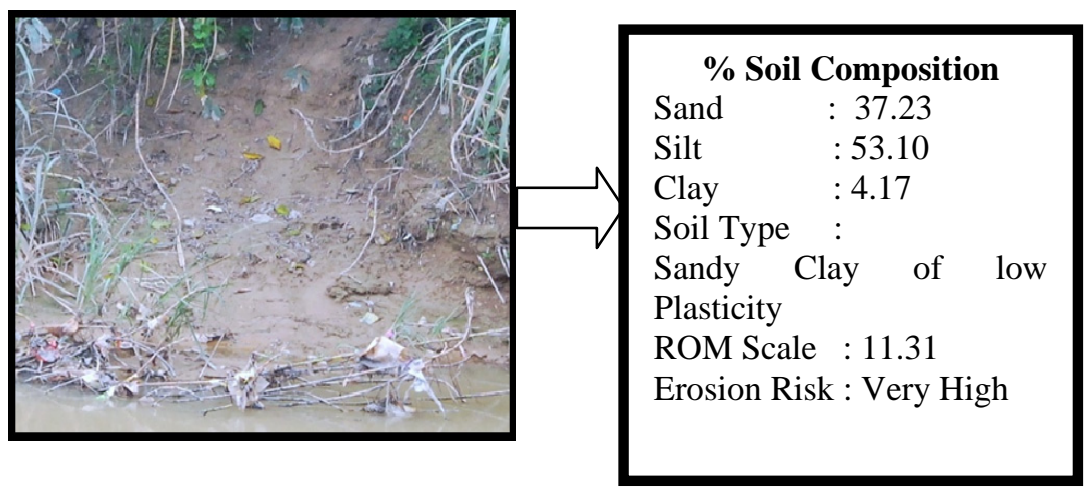

Figure 9: $\quad$ Langat River at Dataran JPS, Sepang district.

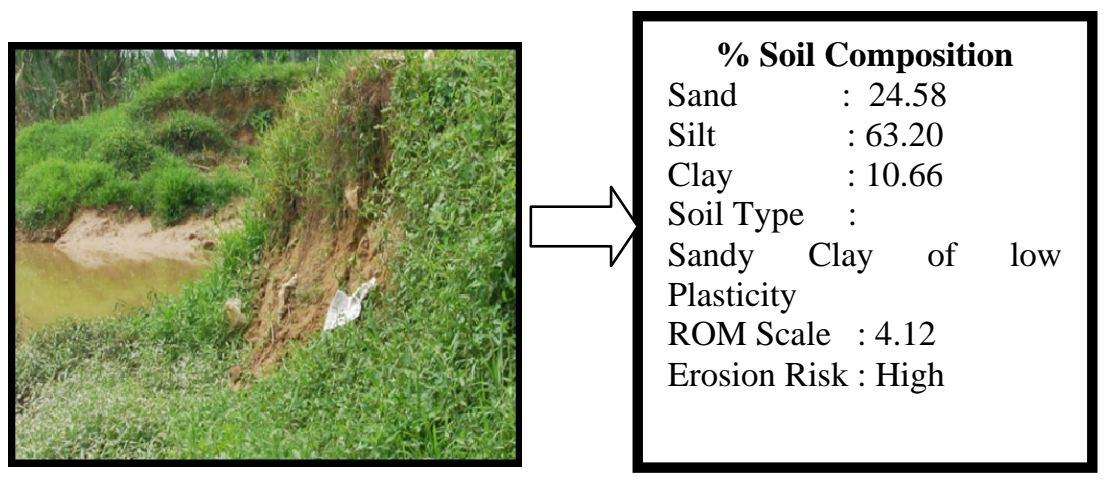

Figure 10: $\quad$ Langat River at Jugra Lama, Kuala Langat district. 
The erodibility factor for a soil can be affected by the composition of sand, silt and clay. High composition of sand and silt means that the soil can easily be eroded since they are fine in size and can be easily carried away by surface run off. From the laboratory test, it was shown that the composition of soil at Hulu Langat district was sandy soil, whereas at Kuala Langat was clayey soil.

\section{Conclusion}

Sheet, Rill and Gully are the three types of soil erosion features that are commonly seen along Langat River. This type of erosion can be easily determined by physical reconnaissance through visual observation at the soil surface. Looking at the type of soil erosion, the riverbank might have the potential of failure. Gully erosion is the most commonly seen compared to sheet erosion. Most of the soil classifications along Langat River have sand and silt based commonly known as Well Graded Silty Sand, Sandy Clay of Low Plasticity and Very Clayey Sand. Basically, soils that have a higher percentage of sand will have higher risk of failure. This is justified and confirmed by the "ROM" Scale equation where most of the soil samples were categorised as very high and critical in the degree level of erosion risk and thus will lead to risk of riverbank failure. With this significant information, early preventive measures can be taken by the responsible authority to prevent untoward incidence along the Langat River.

\section{References}

[1] Smyth AJ, Montgomery RF, Soils and Land Use in Central Western Nigeria. Government Printer, Ibadan. Nigeria p.265, 1962.

[2] Sharifah Mastura , Sabry Al-Tourm, Othman Jaafar, Rainsplash erosion: A case study in Tekala River Catchment East Selangor Malaysia, Georafia Online Malaysian Journal of Society and Space 2 (43-57), 2006.

[3] Mohd Ekhwan Toriman, Zulkifli Yusop, Mazlin Mokhtar and Hafizan Juahir, Application of GIS for Detecting Changes of Sungai Langat Channel, Malaysian journal of Civil Engineering 18(1): 59-70 (2006).

[4] Nor Azwady Abd Aziz, Yan Yib Wei, Muskhazli Mustafa and Aziz Arshad Ecology of Aquatic Worms in the Langat River, Selangor, research Journal of Fisheries and Hydrology, 5(1):14-20, 2010.

[5] Adam Kertesz, Environmental Conditions of Gully Erosion in Hungary, Hungarian Geographical Bulletin, volume 58, pp 78-79, 2009.

[6] Bouyocous GJ. Hydrometer method improved for making particle size analysis of soil. Agr. J. 54: 3, 1962.

[7] Morgan, K.M. and Nalepa, R., Application of Aerial Photographic and Computer Analysis to The USLE for Areawide Erosion Studies, J. Soil and Water Cons., 37(6): 347-350, 1982.

[8] Roslan, Z.A \& Mazidah, M. Establishment of Soil Erosion Scale With Regards to Soil Grading Characteristic. 2nd World Engineering Congress, Sarawak, Malaysia, pp. 235-239, 2002. 